\title{
THE PATTERN OF ADEQUATE HOUSING RIGHTS FULFILLMENT IN INDONESIA
}

\author{
Maria Madalina, Hari Purwadi, Adriana Grahani Firdausy, Achmad. \\ Faculty of Law, Universitas Sebelas Maret \\ E-mail : achmad@staff.uns.ac.id
}

\begin{abstract}
The fulfillment of adequate housing is the part of the fulfillment of human rights as stated in the constitution. The state can not ignore and have to do it when he has the ability to comply the adequate housing for poor people. Adequate housing is more than material it is correlated with the human existence, hence it is categorized as human rights. As part of human rights, the fulfillment of this adequate housing is need to be respect, comply, and protect either by the state and society. The state need to take part to the fulfillment of adequate housing for those who can not afford it. As the state have the capability to realize the adequate housing for the poor, they can not ignore the human rights unfulfillment. This research focused on law guarantee recognition and the pattern of the adequate housing fulfillment in Indonesia. It is revealed that the pattern is correlated with the state political law which is the policy in the form of laws and local regulation that decided the direction, purpose, and the law substance in housing. Beside its society, the policy also need the private sector involvement, as a result the fulfillment of the adequate housing rights has to be done by the three party.
\end{abstract}

Keywords: human rights, adequate housing, and constitution.

\section{A. INTRODUCTION}

Housing is a human basic need either as individual or as a family lives which cannot be ignored. A house is the space where human can grow and it also determines how family members interact with each other and their environment. House can be a place to create family lives, which will be the element to build wider social environment. That is why a house describes a place with a good and healthy condition to grow the member of family or a person, it also give hospitality to those who lives on it. These condition generates what so called "rumah layak huni" ("adequate house) which has the antonymous "rumah tidak layak huni" (unadequate house) unadequate house in the other ways will describes unhealthy, uncomfortable for those who lives on it which in general explained a bad condition for a person or a family to lives on it. 
The fullfillment of adequate housing is one of international issues. Housing is the basis of stability and security for an individual or family. The centre of our social, emotional and sometimes economic lives, a home should be a sanctuary; a place to live in peace, security and dignity. (https://www.ohchr.org/EN/Issues/Housing/Pages/HousingIndex.aspx). The rights is already recognize and respect in international. United nations Human Rghts office of the hight commissioner take adequate house issue as strategic issue that has to be realized in all over the world.

Indonesia already protect to it's citizens in the matter of adequate house and also protect to its citizen in finding a healthy neighborhood through article $28 \mathrm{H}$ on it's constitution. States has the responbility to protect all citizens in increasing public wealty through house bulding in order to get and live in affordable adequate house in healthy, safe, harmony, and sustainable in all over Indonesia. (Urip Santoso, 2014: 2). Nevertheless, its fullfillment still face challenges at least in the matter of house existence. The neccesity of 800.000 unit per a year can only be covered by government in the scale of 200.000 unit /year it give 15 billion unit total house deficiency. Indonesia slum area is in the range of 59 ha with 7,5 billion unadequate house (Kompas, 17 Oktober $2014: 1$ ).

The research toward adequate house fulfillment as guaranted by constitution need to be done since that the constitutional protection in fact is still far away from social reality this also in quest of finding the pattern public prosperity fulfillment.

\section{B. PROBLEM STATEMENT}

In accordance with the theme above, this research focuses on the acknowledgment of legal guarantee and the pattern of fulfillment adequate housing in Indonesia.

\section{RESEARCH METHODS}

This is socio-legal research hence it is interdisciplinary, combine legal doctrine and social studies to the law, both in theory and method. By using the phrase Mark Van Hoecke, the science of law (legal doctrine) is placed as an empirical discipline (Mark Van Hoecke, 2011: 5-6). Therefore, law is seen as part of an "objective" reality. 


\section{DISCUSSION AND RESEARCH RESULT}

1. The rights to adequate housing In Indonesia

A stronger affirmative power of moral responsibility to guaranty the right of housing for its citizens is given since Indonesia is member of United Nation. Indonesia has enLawed Law No. 39 of 1999 on Human Rights, which in its consideration mentions that Indonesia is a member of United Nations, to assume moral and legal responsibility, to uphold and implement the Universal Declaration, as well as other various international instruments on human rights which have been accepted by the Republic of Indonesia. Article 40 of the Law stated that "every person has the right to life and life in a decent way"(Budi Prayitno et al, 2012 : 14).

Besides that as part of an international community who sign the declaration of Rio De Janeiro, Indonesia has always been active in activities initiated by the United Nations Center for Human Settlements. The declaration of Rio De Janeiro generates what so called The Agenda 21 and Habitat Declaration II which has the spirit of adequate housing for all with its slogan: housing is the basic need and becomes the right to adequate and affordable housing for all. The agenda underlined the importance of the housing as human rights which in accordance with the spirit of the 1945 Constitution of The Republic Indonesia.

An acknowledgment on adequate housing is given on Indonesian constitution. Article $28 \mathrm{H}$ verse (1) stated that: "Every person shall have the right to live in physical and spiritual prosperity, to have a home and to enjoy a good and healthy environment, and shall have the right to obtain medical care". On 28 October 2005, Indonesian Government has established the International Covenant on Economic, Social and Culture (ICESCR) with the Law No 11/2005 and International Covenant on Civil and Politic (ICCPR) with the Law of 12/2005. Dengan demikian selain menjadi bagian dari sistem hukum nasional maka kedua kovenan ini sekaligus melengkapi empat perjanjian pokok yang telah diratifikasi sebelumnya, yaitu Convention on the Elimination of All Forms of Discrimination against Women (CEDAW) ratified with the Law Number 7 Year 1984 on 
ratification of Convention on the Elimination of All Forms of Discrimination against Women, Convention on the Rights of the Child ratified with the the presidential decree Number 36 Year 1990 on ratification of Convention on the Rights of the Child, Convention against Torture and Other Cruel, Inhuman or Degrading Treatment or Punishment ratified with the Law Number 5 Year 1998 on the ratification of the convention against Torture and Other Cruel, Inhuman or Degrading Treatment or Punishment, International Convention on the Elimination of All Forms of Racial Discrimination ratified with the Law Number 29 Year 1999 on The Ratification of the International Convention on the Elimination of All Forms of Racial Discrimination. With those ratifications, Indonesia gave strong basic law on the fulfillment of the housing rights with regards to the human rights principle.

As Indonesia has already legally binding through ratification, it gives effect to the human rights implementation. One of them is government has adopted treaty ratified in laws either in the form of bill or laws that already valid. Another is that the government has responbility to take part in any policy to respect, to protect and to fullfil human rights, which followed by another government responbility to make a report regarding legal harmonization, steps, policies, and actions that need to be done.

After ratified ICCPR and ICESCR, Indonesia has binding obligations to make a legal reform defining ICCPR and ICESCR principle and rules in to national law. Government also need to harmonized the national law with the ICCPR and ICESCR framework. All the laws that do not fit with the ICCPR and ICESCR must be revised.

Article 11 verse (1) of the Law No 11/2005 (The Ratification of International Covenant on Economic, Social, and Culture) stated that: Recognize the Right for all to an adequate standard of living including basic income, food, housing, water, sanitation and clothing and the continuous improvement of living conditions. 
As a member of the covenant, Indonesia has the responsibility to guarantee the fulfillment of adequate housing with regard to the nondiscrimination. In housing, discrimination can take the form of discriminatory laws, policies or measures; zoning regulations; exclusionary policy development; exclusion from housing benefits; denial of security of tenure; lack of access to credit; limited participation in decision-making; or lack of protection against discriminatory practices carried out by private actors. (The Right to Adequate Housing Fact Sheet No. 21/Rev.1, 2014: 10).

Economic, social, and culture rights are different with the civil and political rights whereby economic, social, and culture should be realize gradually, as stated in article 2 verse (1). "every states of the covenant are individually or through legal aid and international cooperation trying to gradually realize of the fulfillment of the rights recognized with this covenant in every adequate way especially legislative action". (Rhona K.M. Smith et al, 2008. 136).

Arturs Kucs, Zane Sedlova \& Liene Pierhurovica on The Right to Housing: International, European and National Perspectives stated regardless of the ICESCR, others international instrument is taking adequate housing as a right, which is ratified by the states. Most of them protect the housing needs of specific social groups such as children, refugees, migrant workers, indigenous people, the disabled, and other vulnerable groups. Other instruments as the Convention on the Elimination of All Forms of Racial Discrimination and the Convention on the Elimination of All Forms of Discrimination Against Women strengthen the application of the principle of equality and non-discrimination to ensure the enjoyment of housing rights by these disadvantaged groups. (Arturs Kucs, Zane Sedlova \& Liene Pierhurovica, The Right to Housing: International, European and National Perspectives accessed from http://www.corteidh.or.cr/tablas/r26740.pdf on 13 November 2016, 20.00 wib).

Others international convention enrich the principal rights of housing fulfillment, i.e: the fulfillment of this right must pay attention to the non-discrimination of the race, skin color, nationality, the origin of ethnic, and equality of the women and 
men rights, facilitated to help the oldest to protect child adequate housing rights. International Labour Organization (ILO) also established two conventions on housing rights. While, the fulfillment of the housing rights for the refugees is stated on the International Convention Relating to the Status of Refugees (1951) (A. Patra M. Zen, 2004: 3).

In a specific way, the acknowledgment of adequate house fulfillment is stated in the law no 1/2011 on House and Housing Area. There are 4 basic reasons on the enactment of Law No 1/2011 as stated on its consideration, which are: 1) as the basic need of human, every person has the rights to lives spiritually and materially prosperous, living and having a find and healthy neighborhood which have the strategic role in creating Indonesian characteristic as a way to create a complete Indonesian human which have self-identity and productive; 2) states responsible to protect every Indonesian through the house and housing organization in order to live in affordable and adequate house in healthy safe, harmonious, and sustainable in all over Indonesia; 3) government need have more role supporting housing supply and housing area based on area and citizens independency to create fungtional unity in the form physical layout, economic life, social and cultural, which can guarantee living environment preservation in a way with the democracy spirit, decentralization, transparence in society, notion, and state; 4) the growth and development area which less low income public interest considerable create difficulties in having affordable and adequate house. Nevertheless law no 23/2014 on Local government also has strategic role in the realization of adequate house. States political law shows that every central government policies need to has synergy with local government who has more situational and condition understanding and also know more about poverty map in local which has to be solve through adequate house.

Based on the analysis it is clear that Indonesia already recognizes the housing rights. Adequate housing rights can be asked since it is guaranteed by the constitution. An awareness to human rights is needed in order to realize it, people must know the rights that they can get, and advocacy is needed to guard the rights in 
order to get protected by the constitution and to make government priority to create people welfare.

\section{Adequate Housing Criteria and the Fulfillment}

Housing development has a purpose in giving adequate house for family in healthy, safe, harmonious, regular area. At least a building need to has safety building, adequacy minimum range, health of the inhabitant so it can be called adequate house. The area has to meet the layout qualification, land use qualification, land ownership, properness of facilities and infrastructure.

As a basic need, United Nations already decided that housing is the people rights. Rights of housing are the most important construction to fulfill the economic, social, and cultural rights. Housing rights identify the real Lawion for the guarantee and the fulfillment of adequate living rights.

Housing means an Lawion to housinging or to guarantee the fulfillment need of housing. Housing is people basic needs and an important thing to increase man dignity. Public policy on developing housing, institutional, land issues, financing, and the elements supporting developing housing are the things that need to get attention to fulfilling the rights.(Komarudin, 1997: 46). Housing rights is an essential element that could strengthen the fulfillment of another fundamental right i.e food rights, health, etc. (Majda El Muhtaj, 2009: 142).

A Report written by Raquel Rolnik on 2013, (www.ohchr,org/EN/HRBodies, on 13 November 2016, 22:30 wib.) revealed that: In the last decade, Indonesia has enjoyed steady economic growth and demonstrated substantial gains in social indicators, with gradual declines in poverty in both urban and rural areas, and is now classified as a middle-income country. Despite these impressive achievements, about 28.6 million people or 11.6 percent of all households still live below the national poverty line set at US\$ 1.25 per day. In addition, a significant part of the population (38 percent) lives below 1.5 times the poverty line and is extremely vulnerable to falling into poverty. Indonesia is the world's third most populous 
country and currently has the largest share and the fastest rate of growth of urban population in Asia. The number of urban poor is expected to rise as the country's urbanization rate is projected to increase from its current level of 50 percent to a projected 70 percent by 2030 .

The urban poor is concentrated in highly urbanized and densely populated Java, accounting for more than two-thirds of the country's low-income population. Internal migration from rural to urban areas is partly caused by the concentration of economic Lawivity in urban centers. Additionally, commercial agriculture development and extrLawive industries in rural areas compete with traditional economic Lawivities for land and natural resources pushing people to migrant to the cities. Although economic decentralization is part of the Government's general development agenda, the inertia of the historical concentration of economic opportunities in Java is still challenging its housing policies - the improvement and upgrading of existing housing conditions, and the provision of adequate housing opportunities for future growth. The high and fast demographic and economic concentration across Java and on Bali, especially in the country's two largest metropolitan regions, Jakarta and Surabaya, pose a number of difficulties, including congestion, overcrowding, inadequate provision of affordable land, inadequate transportation systems and a massive infrastructure backlog. The combination of rapid urbanization, population density, and high poverty rates poses serious challenges to the realization of the right to adequate housing for all in Indonesia. These challenges are compounded by the fLaw that the majority of Indonesia's territory is highly vulnerable to climate change and natural disasters, particularly flooding, volcanic eruptions, and earthquakes.

Based on that reports, Indonesia still has a high the level of poverty above 28 million people or at least 11,6 percent. For Indonesia especially on big cities in Bali and Java, particularly in Jakarta and Surabaya, the combination of poverty, population density, and urbanization became a serious challenge in the fulfillment of 
adequate housing. This challenges, based on the research also became a serious challenge in Sukoharjo, Solo, and Karanganyar.

There's a problem when we use a United Nations measurement as stated on Indonesian visitation reports: As a party to the International Covenant on Economic, Social and Cultural Rights, Indonesia has the obligation to ensure the enjoyment of the right to adequate housing, while ensuring non-discrimination on any grounds. The right to adequate housing should not be interpreted in a restrictive sense such as merely having a roof over one's head; it includes guaranteeing (a) legal security of tenure; (b) availability of services, materials, facilities, and infrastructure; (c) affordability; (d) habitability; (e) accessibility; (f) location; and (g) cultural adequacy.

The fulfillment of adequate housing must comply with seven criteria mentioned above. It means that a housing right not only to facilitate a living place, but it has to be fit with those 7 (seven) criteria besides the existence of the nondiscrimination living house- and it becomes 9 (nine) criteria. In research location, the local government establish a program called "help" RTLH (Rumah Tidak Layak Huni/ Inadequate housing). One of the nine criteria, "habitability" became one of this "help".

In 2016 local government of Karanganyar gave Rp. 5.000.000,00 up to Rp.7.500.000,00 from the APBN (states budget)-without additional budget from the village, as the implementation of the RTLH programs. The RTLH programs gave a material building support. People should also prepare the individual budget since the help budget is far from enough. Decided with the priority scale (i.e medium or hard damage) not all of inadequate housing got support. Percentage RTLH who obtain assistance each year is smaller compared to the number of RTLH. Only 130 from 12.000 could be realized in Karanganyar, and the rest use ministry, province, or local government budget. (Interviewed with M. Al. Jumairi, Kasi Kaur Wonosari village, Gondangrejo district, 19 July 2016).

RTLH assistance also exists in Sukoharjo in the form simultaneous material to fix the housing, but still, people (in the group consisting of 10 people/families) 
need to cover the shortfall of the assistance. In 2014, the government of Sukoharjo district realized the program of building flats in order to facilitate low-income citizens with proper accommodation and also to overcome the problems of slums. In 2016, Sukoharjo rolled out a program of renovation for 300 (three hundred) RTLH in 30 (thirty) villages and six (6) districts. The community was divided into groups of ten families or home owners each. Each group was eligible to receive a Rp.70.000.000,00 (seventy million) fund which means an average of seven (7) million per family/home owner. Interviewed with Subriyantoro, head of equipment department village, SDA, and TTD BPPDes Sukoharjo, 22 June 2016.

While in Solo, the fulfillment of housing rights implemented with the establishment of the flats and row houses (which will be for rent) besides an assistance to fix the house taken from the local government budget, which is 2016 devoted to $250 \mathrm{RTLH}$, and each person acquiring the help of 7.5 (seven and a half) million, still the assistance require community self-help. (Interviewed with Supriyadi, the assistance of empowerment department, city coordination office, 20 June 2016).

The limitation on RTLH programs shows that the other eight criteria to fulfill the housing rights are unreachable. It is hard to realize the owner of the housing especially the adequate housing as criteria. Indonesia is currently in the midst of a housing affordability crisis especially adequate housing as united nation stated in 2013 reports below: Indonesia is currently in the midst of a housing affordability crisis, as recognized by the Government. The high urban population growth, the shortage of land for housing and urbanized land, and the sharply increasing housing and land prices are limiting the availability of affordable housing, particularly for low- and middle-income households in urban areas and has led to rapid expansion of informal settlements. Less than 8 percent of the housing produced by the housing market costs less than Rp 400 million (US\$ 40,000). With around US\$ 4,000-6,000 per year as average income per capita of the urban population, the majority simply cannot afford to buy a house from the market. (www.ohchr,org/EN/HRBodies, on 13 November 2016, 22:30 wib.). 
Until 2016 this research is still relevant to the United Nations reveals on the fulfillment of adequate housing in the decentralization era in which apparently can't highly increase the fulfillment of the rights. Due to the high financial dependent on central government, local government including Solo, Karanganyar, and Sukoharjo are not independent in the fulfillment of the adequate housing rights. The ability of the local government is affected by the financial assistance of the central government. While based on the united nation on the article 2 (1) of the International Covenant on Economic, Social, and Cultural Rights Indonesia has the obligation to take steps, individually and through international assistance and cooperation, especially economic and technical, to the maximum of its available resources, with a view to achieving progressively the full realization of the rights.

The facts show that central government can not optimally fulfill the adequate housing and neither local government. With regards to human rights and living standard, the government has to set up the housing political law. Half of the Indonesian people are ignored and having a nonstandard life due to the weak housing political law.

\section{The pattern of Adequate Housing Rights Fulfillment}

Both Indonesian constitution law on 1945 and the International Covenant on Economic, Social, and Cultural Rights which has been ratified by Indonesia give strong stressing on the adequate housing political law as a part of human rights. The political law defined as a policy that decides the national law direction, objective, and substance in which give the guarantee of the fulfillment of adequate housing rights.

The objective of establishment housing and habitation district as mentioned in Article 3 letter (e) on the Law of 1 Year 2011 on the housing and habitation district is to ensure the realization of the adequate and affordable housing rights in the healthy, secure, harmonious, integrated, well planned, and continuous places. This objective is relevant to the article 19 of the Law which is stressing on the establishment of the house and housing: 
(1) The implementation of house and housing did fulfill the need of housing as the human basic need for increasing the equitable welfare.

(2) The implementation of house and housing as stated in the verse (1) done by the government, central government or every citizen to guarantee the citizens right to place, to enjoy, and to own an adequate house in the healthy, safe, and integrated places.

That article shows the direction of the fulfillment of the adequate housing rights especially for low-income people in which based on the Law facilitated through the developing public housing. Public housing is a house established to fulfill the housing need for the low-income people (Article 1 number 10). In Solo, Karanganyar, and Sukoharjo Public housing are replaced with the flat or row house for law income and unhousing people.

Since that the local government can not afford the establishment of public housing, they in return gave RTLH assistance in which can not be called as the fulfillment of the adequate housing and this situation shows the local government inability. And this leaving the issue of a program has not met the criteria of the right to appropriate housing as required by the UN. Due to the low financial on the adequate housing, different conditions on the implementation of the rights happened in most of the region at least in Solo, Karanganyar, and Sukoharjo. With the UN nine criteria, this condition is more visible.

Disregards on the inability of local government and unaware of government, there is private domination on housing commodification center in society. Government policy to fulfill the adequate housing is incoherent with the increasingly private sector commodification. It lays social gab due to the increase of the private sector in housing developing in which ignore the government inability to fulfill the adequate housing rights. For that reasons, housing policy needs the participation of private sectors and the poor or low-income society. Local regulation both on "house and housing" and RTLH Assistance still denying the private sector 
participation in solving the housing problems for the poor and the low-income society.

Based on the research done by Marie Huchzermeyer in South Africa the perception of local government (in which having the limited ability) only as a form of implementation of central government program makes bureaucratic constraints on community-based construction. (Marie Huchzermeyer, 2001, "Housing for the Poor? Negotiated Housing Policy in South Africa", Pergamon \& Habitat International 25 (2001), 303-331, https://core.ac.uk/download/pdf/39670666.pdf, on 14 November 2016, 00:57 wib.). In this case, the local government has a policy that oriented in the fulfillment of adequate housing rights obligation, not only implementing the central government policy who has limited capability in reading the fact of the local house and housing.

Since that the Local and central government point of view is constitution base state dominant in public prosperity constitution enforcement, government policies tend to elitist, state know all and people is a policy object. It's time to change the point of view from constitution base state into constitution base on human rights so that government policy is an obligation to give human rights guarantee for affordable adequate house. In this way citizens has to be participated actively in their rights fulfilment.

Looking to that description, fulfillment has to fit with the criteria and living standard as required by UN, in which a series of fulfillment houses, ownership rights, infrastructure, and socio-cultural environment. This policy also needs the private sector and social participation, so that this policy should be supported by three parties.

\section{E. CLOSING}

Due to the fulfillment of the adequate housing rights hasn't met the standard of live and UN criteria, the pattern of the rights fulfillment need to be changed.

The ideal pattern of the right fulfillment related with the political law which is the policy that decides the purpose, objective, and the substance of the housing law 
both in the form of an Law and local regulation. As well as the Law, the district regulation that doesn't put the adequate housing as a right also need to be changed, so that the local government will take the rights as an obligation that needs to be realized. In that regards, financial change in local development is needed.

Restructuring of funding is required within the framework of regional development. This requires restructuring of funding within the framework of regional development. The budget of Public housing development or RTLH assistance has to consider the adequate housing as a right. In the case of the fulfillment of the rights, one big problem for the local government is a dependency on the central government, this situation makes local government become uncreative. The ideal model of the fulfillment of the rights needs the participation of society and private sector who has been oriented in housing commodification perse.

\section{BIBLIOGRAPHY:}

\section{Books:}

Komarudin, 1997, Tracing the House and Housing Development, Jakarta: Yayasan REI, Rakasindo.

Muhtaj, Majda El, 2009, Human right dimensions, Reveals the Economic, Social, Culture Rights, Jakarta: Rajawaji Press.

Smith , Rhona K.M. et al, 2008, Human Rights Law. Yogyakarta: Pusham UII.

Santoso , Urip, 2014, Hukum Perumahan, Jakarta: Kencana Prenada Media Group.

\section{Journals:}

Hoecke , Mark Van., "Methodologies of Legal Research, Which Kind of Method, What Kind of Discipline?", Oxford and Portland, Oregon: Hart Publishing, 2011.

Prayitno, Budi et al, "Wealth for the Poor, The Acceleration of living fulfillment", Jakarta: In Cooperation With The Ministry of People Wealth Coordinator With The Technical Faculty, University of Gadjah Mada, 2012.

Zen , A. Patra M., "People rights on Housing: Creating a Framework for Evaluation of the realization of the Government's Rights", ELSAM: Jakarta, 2004. 


\section{Articles taken from websites:}

Kucs ,Arturs, Zane Sedlova \& Liene Pierhurovica, "The Right to Housing: International, European and National Perspectives", accessed from http://www.corteidh.or.cr/tablas/r26740.pdf accessed on 13 November 2016, 20.00 West Indonesian Time (WIB).

https://www.ohchr.org/EN/Issues/Housing/Pages/HousingIndex.aspx

Marie Huchzermeyer, 2001, "Housing for the Poor? Negotiated Housing Policy in South Africa", Pergamon \& Habitat International 25 (2001), 303-331, https://core.ac.uk/download/pdf/39670666.pdf, accessed 14 November 2016, 00:57 wib.

Raquel Rolnik, "Report of the Special Rapporteur on adequate housing as a component of the right to an adequate standard of living, and on the right to non-discrimination in this context, Twenty-Fifth Session, Agenda item 3, Promotion and protection of all human rights, civil, political, economic, social and cultural rights, including the right to development, Human Rights Council, General Assembly, United Nations", 2013.

Www.ohchr,org/EN/HRBodies, accessed on 13 November 2016, 22:30 WIB.

\section{Documents}

Interviewed by M. Al. Jumairi, Kasi Kaur Wonosari village, Gondangrejo district, 19 July 2016.

Interviewed with Subriyantoro, head of equipment department village, SDA, and TTD BPPDes Sukoharjo, 22 June 2016.

Interviewed with Supriyadi, the assistance of empowerment department, city coordination office, 20 June 2016

\section{Laws and Regulations:}

1945 Constitution of the Republic of Indonesia

Law Number 1 of 2011 on The Housing and Settlement Areas (State Gazzette Number 7 of 2011)

Law Number 23 of 2014 on The Regional Government (State Gazzette Number 244 of 2014)

Law Number 29 of 1999 on The Ratification of the International Convention on the Elimination of All Forms of Racial Discrimination (State Gazzette Number 63 of 1999) 
Law Number 5 of 1998 on the ratification of the convention against Torture and Other Cruel, Inhuman or Degrading Treatment or Punishment (State Gazzette Number 164 of 1998)

Law Number 7 of 1984 on The ratification of Convention on the Elimination of All Forms of Discrimination against Women (State Gazzette 29 of 1984)

Presidential Decree Number 36 of 1990 on The ratification of Convention on the Rights of the Child (State Gazzette Number 57 of 1990) 